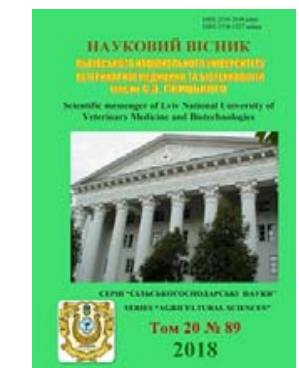

\author{
Науковий вісник Дьвівського національного університету \\ ветеринарної медицини та біотехнологій імені С.3. Гжицького
}

\author{
Scientific Messenger of Lviv National University \\ of Veterinary Medicine and Biotechnologies
}

ISSN 2519-2698 print

ISSN 2518-1327 online doi: $10.32718 /$ nvlvet8905

http://nvlvet.com.ua/

UDC 636.2.034 / 57.087

\title{
Analysis of Genotype $\times$ Environment Interaction for milk production in dairy cow
}

\author{
S.S. Kramarenko, N.I. Kuzmichova, A.S. Kramarenko \\ Mykolayiv National Agrarian University, Mykolayiv, Ukraine
}

Article info

Received 30.08.2018

Received in revised form 27.09 .2018

Accepted 29.09.2018

Mykolayiv National Agrarian University, Georgiva Gongadze Str., 9, Mykolayiv, 54020, Ukraine. Tel.: +38-050-991-53-14 Email: kssnail0108@gmail.com

\begin{abstract}
Kramarenko, S.S., Kuzmichova, N.I., \& Kramarenko, A.S. (2018). Analysis of Genotype $\times$ Environment Interaction for milk production in dairy cow. Scientific Messenger of Lviv National University of Veterinary Medicine and Biotechnologies, 20(89), 27-34. doi: 10.32718/nvlvet8905

Genotype by environment interaction was studied with 526 lactation milk records of Red Steppe dairy cows maintained at State Enterprise "Breeding reproducer "Stepove" (Mykolayiv region, Ukraine). The analyses in this study were based on the milk yields of cow per $1^{\text {st }}-10^{\text {th }}$ month (M1-M10) and per 305 day for complete lactations (Y305). We tested the hypotheses that milk performance were influenced by the sire (factor "Sire"), by number of lactation (factor "NoL"), by of cow's year of born (factor "Generation") and by the season of calving (factor "SoC"). The data were analysed with the "Variance components" and the "ANOVA/MANOVA" modules of statistical software STATISTICA (StatSoft Inc, USA). Experimental cows originated from five sires. The effect of the sire was significantly expressed in milk yield from the $2^{\text {nd }}$ to $7^{\text {th }}$ month of lactation (in all cases: $P<0.001-0.024)$ and $Y 305(P=0.011)$. The 12-year period studied (year of cow's birth from 2001 to 2011) was classified into four periods as follows: G1 - 2001-2003, G2 - 20042006, G3 - 2007-2009 and G4 - 2010-2011. Year of birth (factor "Generation") had significant (in all cases: $P<0.001-0.044)$ effect on all traits studied (but not on M7-M8). All cows were divided according to the season of calving (SoC): winter (December to February), spring (March to May), summer (June to August) and autumn (September to November). The production of milk for M1-M2, M4-M8 and M10 (but not for 305 day lactation) statistically differed according to the season of calving (in all cases: $P<0.05$ ). From the study results, a significant relationship was found between the milk yield and lactation number, with the maximum milk yield occurring in the third lactation cows (pattern $1<2<3=4+$ ). Milk yields from the M1 to M6 month of lactation (in all cases: $P<0.001-0.017)$ and Y305 $(P<0.001)$ were statistically different between cows according to the number of lactation. Cow's lactation number, year of birth and calving season causes differences in the shape and persistency of lactation curve. Genotype by environment interactions for lactation number and cow's year of birth can be result in re-ranking of sire between the different environments.
\end{abstract}

Key words: genotype by environment interaction, sire, lactation number, calving season, generation, dairy cow.

\section{Аналіз взаємодії “генотип $\times$ середовище" на молочну продуктивність корів}

\author{
С.С. Крамаренко, Н.І. Кузьмічова, О.С. Крамаренко
}

Миколаӥвський національний аграрний університет, м. Миколаїв, Украӥна

\footnotetext{
Аналіз ефекту взаємодії “генотип × середовище” було досліджено на прикладі 526 лактачій корів червоної степової породи, що утримувалися в умовах ДП "Племрепродуктор “Степове” (Миколаївська область, Украӥна). Всі дослідження було проведено на підставі даних щодо надоїв корів за 1-10-й місяиі (M1-M10) та 305 днів закінчених лактацій (Үзо5). Нами було перевірено гіпотези щодо впливу на молочну продуктивність наступних факторів - бугая-плідника (фактор "Sіге”), номера лактаиії корів (фактор “NoL”), їх року народження (фактор “Generation”) та сезону їх отелення (фактор “SоC”). Дані було проаналізовано з використанням модулів "Компоненти варіанси” та “Дисперсійний аналіз” пакету прикладних програм STATISTICA (StatSoft Inc, USA). Корови, що було включено до аналізу, походили від n'яти бугаїв-плідників. Встановлено вірогідний вплив бугая-плідника на надої їх дочок протягом 2-7-го місяия лактаиії (у всіх випадках: $P<0,001-0,024)$ та за 305 днів лактаиії $(P=0,011)$. 12-річний період дослідження (корови народжені протягом 2001-2011 рр.) було поділено на чотири інтервали таким чином: G1 - 2001-2003, G2 2004-2006, G3 - 2007-2009 та G4 - 2010-2011 рр. Рік народження корови (фактор “Generation”) вірогідно впливав (у всіх випадках: $P<0,001-0,044)$ на всі досліджені ознаки (за виключенням надою за 7-8-й місяиі лактації). Відповідно сезону отелення (фак-
} 
тор “SоС”) тварини було поділено на групи: із зимовим (з грудня по лютий), весняним (з березня по травень), літнім (з червня по серпень) та осіннім отеленням (з вересня по листопад). Молочна продуктивність за 1-2-ц̆, 4-8-й та 10-й місяці лактації (але не за 305 днів) вірогідно залежала від сезону отелення (у всіх випадках: $P<0,05)$. На підставі отриманих результатів встановлено вірогідний вплив номера лактації на рівень молочної продуктивності, максимальний прояв якого було відмічено для 3-ої лактації (патерн $1<2<3$ = 4+). Вірогідний вплив номеру лактації корів було відмічено на їх надої за 1-6-й місяці (у всіх випадках: $P<0,001-0,017)$, а також 305 днів лактації $(P<0,001)$. Номер лактації, рік народження та сезон отелення впливав на форму та персистентність лактаційних кривих корів. Аналіз ефекту взаємодії “генотип × середовище”, шчо було встановлено для номеру лактації та року народження корів, може бути результатом ефект зміни рангу (re-ranking еffect) бугаїв-плідників в різних умовах середовища.

Ключові слова: взаємодія “генотип × середовище”, бугай-плідник, номер лактацї, сезон отелення, генерація, молочна худоба.

\section{Вступ}

Рівень прояву продуктивних ознак сільськогосподарських тварин (у т. ч., корів) залежить від їхньої спадковості (пулу генів, отриманих від батьків) та формується під впливом навколишнього середовища, в якому тварина вирощувалася та/або утримувалася під час всього терміну господарського використання. Обидва ці чинники є важливими, оскільки як спадковість, так і фактори навколишнього середовища можуть лімітувати продуктивність тварини. Для селекціонерів найбільший інтерес становить оцінка сили впливу генетичних та систематичних паратипових факторів на фенотипову мінливість продуктивних ознак тварин. Оцінки генетичних параметрів повинні бути ревалентні для тієї популяції та умов навколишнього середовища, в яких тварини будуть використовуватися (Kuznecov, 2001).

Прояв взаємодії “генотип × середовище" (GEI Genotype $\times$ Environment Interaction) розглядається як зміна відносного значення ознаки двох (або більше) генотипів, що було оцінено для двох (або більше) градацій фактору “середовище”. Загалом, GEI-ефект проявляється, коли рівень продуктивності для різних генотипів обумовлюється різними умовами середовища не в рівній мірі, тобто відмінності між окремими генотипами не залишаються однаковими у різних умовах середовища (Falconer and Mackay, 1996). В огляді (Montaldo, 2001) GEI-ефект розглядається як наявність адитивної мінливості, що є проявом сумісного впливу генотипу та середовища, який не може бути оцінений лише на підставі їх окремих середніх ефектів. Ним же надано і класифікацію основних типів GEI-ефекту, залежно від рівня мінливості генетичного та середовищного факторів. Врахування GEIефекту дозволяє отримувати точніші оцінки племінної цінності (EBV) тварин.

В молочному скотарстві як градації фактора “генотип” можна розглядати окремих бугаїв-плідників, окремі внутрішньопородні одиниці (наприклад, лінії) або навіть окремі породи. В огляді (Hayes et al., 2016) наведено особливості формування прояву GEI-ефекту для геномного рівня (SNP-генотип).

Як градації фактора “середовище” можна використовувати різноманітні умови утримання тварин. Це можуть бути фізичні та/або кліматичні відмінності між окремими країнами (чи регіонами), в яких утримуються однакові генотипи (Hayes et al., 2003; Zwald et al., 2003; Haile-Mariam et al., 2008; Montaldo et al., 2015), відмінності окремих елементів технології утримання тварин та рівні їх продуктивності (Hayes et al., 2003; Nauta et al., 2006; Sundberg et al., 2010; van der Laak et al., 2016), різні періоди дослідження (Ron and Hillel, 1983) та ін.

Таким чином, головною метою нашої роботи став аналіз впливу GEI-ефекту на молочну продуктивність корів і можливості використання цього ефекту в племінній роботі для корекції оцінки племінної цінності бугаїв-плідників. Оскільки загальний рівень молочної продуктивності формується на підставі накопичення надою за окремі етапи лактації, то нами було проведено аналіз GEI-ефекту як у розрізі надою за 305 днів лактації загалом, так і за окремі її місяці.

\section{Матеріал і методи досліджень}

Матеріалом для дослідження слугували дані зоотехнічного обліку корів червоної степової породи, що утримувалися у ДП "Племрепродуктор "Степове" Миколаївського району Миколаївської області протягом 2001-2014 pp. Всього було проаналізовано 526 повних лактацій.

Як ознаки молочної продуктивності корів були використані дані щодо їхнього надою за десять місяців (M1-M10) та сумарний надій за 305 днів закінченої лактації (Ү305). Всі вихідні дані було попередньо стандартизовано (на тривалість 30,5 днів для кожного місяця лактації) на підставі методу нелінійної апроксимації за методикою (Kramarenko, 2008).

Як градації фактора “генотип” було використано п’ять бугаїв-плідників, що були батьками дослідних корів (фактор "Sire"; Памір 6467, Орфей 2719, Тангенс 22510, Нарцис 2543, Тополь 2613). Як градації фактора “середовище” було використано: номер лактації (фактор "NoL"; 1-я, 2-a, 3-я та 4-а і вище), генерація (фактор “Gen”; G1 - 2001-2003 рік народження, G2 - 2004-2006 рік народження, G3 - 2007-2009 рік народження, G4 - 2010-2011 рік народження) та сезон отелення корів (фактор "SoC"; S1 - грудень-лютий; S2 - березень-травень; S3 - червень-серпень; S4 вересень-листопад).

На першому етапі аналізу було визначено вірогідність впливу використаних градацій як генотипового, так і негенотипового факторів на рівень мінливості молочної продуктивності як за окремі місяці лактації, так й за 305 днів загалом. На другому - було проведено оцінку рівня значущості прояву GEI-ефекту для різних типів взаємодії “генотип × середовище": “бугай-плідник × номер лактації корови”, “бугай-плідник $\times$ генерація корови" та "бугай-плідник $\times$ сезон отелення корови". Всі розрахунки було проведено за допомогою модулів “Компоненти варіанси" та “Дис- 
персійний аналіз" пакету прикладних програм STATISTICA (StatSoft Inc, USA) (Halafyan, 2007).

\section{Результати та їх обговорення}

Рівень молочної продуктивності корів дослідного стада (як за окремі місяці лактації, так і за 305 днів) вірогідно залежав від генотипового фактора (бугайплідник) (табл. 1). Особливо, це проявлялося під час 3-6-го місяців лактації, тобто протягом періоду максимальної реалізації молочної продуктивності тваринами. 3 іншого боку, перший (M1) та два останні місяці лактації (М9 та М10), характеризувалися значною випадковою компонентою (в усіх випадках: P > 0,05). Суттєві відмінності між надоями за окремі місяці серед корів різного походження обумовлювали формування лактаційних кривих різної форми (рис. 1).

Таблиця 1

Результати дисперсійного аналізу впливу різних факторів на ознаки молочної продуктивності корів

\begin{tabular}{|c|c|c|c|c|c|c|c|c|}
\hline \multirow{3}{*}{ Ознаки } & \multicolumn{8}{|c|}{ Фактор } \\
\hline & \multicolumn{2}{|c|}{ Sire } & \multicolumn{2}{|c|}{ NoL } & \multicolumn{2}{|c|}{ Gen } & \multicolumn{2}{|c|}{ SoC } \\
\hline & $F_{4 ; 502}$ & $P$ & $F_{3 ; 522}$ & $P$ & $F_{3 ; 522}$ & $P$ & $F_{3} ; 522$ & $P$ \\
\hline M1 & 0,70 & ns & 23,02 & $<0,001$ & 8,04 & $<0,001$ & 4,93 & 0,002 \\
\hline M2 & 2,82 & 0,024 & 57,52 & $<0,001$ & 19,87 & $<0,001$ & 6,37 & $<0,001$ \\
\hline M3 & 6,63 & $<0,001$ & 50,81 & $<0,001$ & 16,64 & $<0,001$ & 1,53 & ns \\
\hline M4 & 8,92 & $<0,001$ & 25,33 & $<0,001$ & 9,57 & $<0,001$ & 3,94 & 0,008 \\
\hline M5 & 8,08 & $<0,001$ & 9,72 & $<0,001$ & 4,96 & 0,002 & 8,41 & $<0,001$ \\
\hline M6 & 6,07 & $<0,001$ & 3,44 & 0,017 & 2,72 & 0,044 & 10,19 & $<0,001$ \\
\hline M7 & 3,66 & 0,006 & 1,07 & $\mathrm{~ns}$ & 1,69 & $\mathrm{~ns}$ & 8,40 & $<0,001$ \\
\hline M8 & 1,49 & ns & 0,28 & $\mathrm{~ns}$ & 2,14 & ns & 4,06 & 0,007 \\
\hline M9 & 1,01 & ns & 0,14 & $\mathrm{~ns}$ & 4,43 & 0,004 & 1,59 & $\mathrm{~ns}$ \\
\hline M10 & 2,24 & $\mathrm{~ns}$ & 0,20 & $\mathrm{~ns}$ & 6,87 & $<0,001$ & 3,46 & 0,016 \\
\hline Y305 & 3,33 & 0,011 & 19,49 & $<0,001$ & 10,81 & $<0,001$ & 1,42 & ns \\
\hline
\end{tabular}

Примітка: $\mathrm{ns}-\mathrm{P}>0,05$

Серед генетичних факторів, що суттєво впивають на рівень молочної продуктивності корів, одним 3 найбільш важливих $є$ вплив їхнього батька (Broucek et al., 2004; Hammoud et al., 2010; ElBoshra et al., 2016) або його лінії. Так, нащадки чорно-рябих або червоно-рябих голштинських бугаїв вірогідно відрізнялися за середніми прижиттєвими добовими надоями їх дочок (Adamczyk et al., 2017). Було також встановлено, що походження тварин впливає на форму їхньої лактаційної кривої, що позначилося насамперед на рівні пікового значення надоїв протягом 2-3-го місяців їх лактації (Horan et al., 2005).

Вік корів (виражений у порядковому номері лактації) суттєво впливав як на сумарний надій за 305 днів лактації, так і на надої протягом перших шести місяців лактації (див. табл. 1).

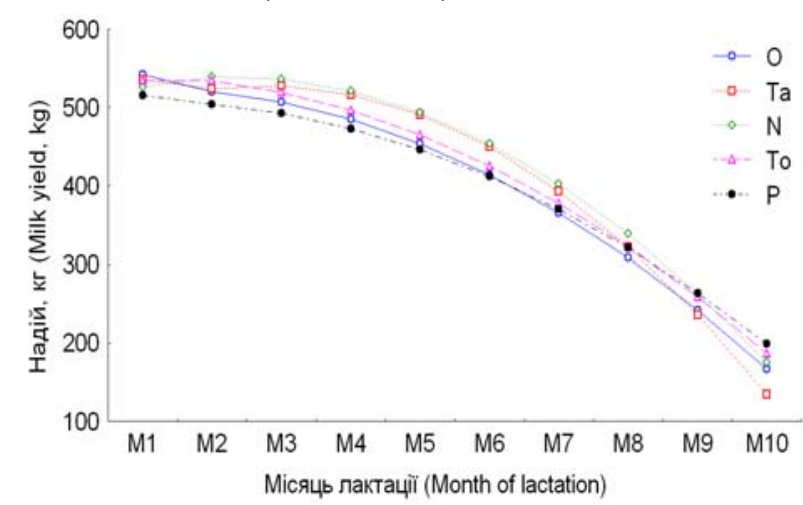

Рис. 1. Лактаційні кривих корів, що походили від різних бугаїв-плідників: О - Орфей, Та -Тангенс, $\mathrm{N}$ - Нарцис, То - Тополь, $\mathrm{P}$ - Памір
Водночас як надої протягом другої половини лактації (яка характеризується повільним зниженням молочної продуктивності корів), навпаки, ніяким чином не залежали від порядкового номера їхньої лактації.

Лактаційна крива первісток характеризується практично однаковими надоями протягом першої половини лактації, після чого вони поступово знижувалися (рис. 2).

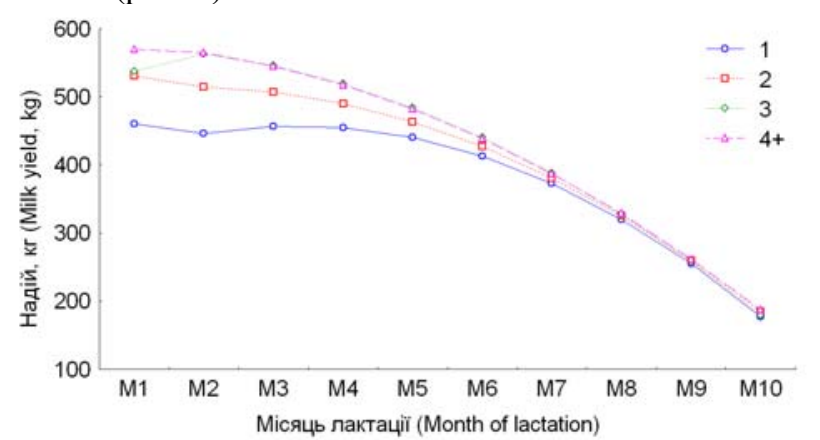

Рис. 2. Лактаційні кривих корів залежно від віку (у лактаціях)

Зі збільшенням номера лактації зростали насамперед надої за перші три місяці лактації. Але серед тварин із трьома та більше лактаціями рівень молочної продуктивності досягав максимально можливого рівня і форма їхніх лактаційних кривих вже практично не відрізняється між собою (див. рис. 2).

Численні опубліковані дані свідчать про наявність двох типових патернів вікової мінливості молочної продуктивності корів. В першому випадку відмічаєть- 
ся вірогідне збільшення надою (за 305 днів лактації або середньодобового за всю лактацію) від 1-ої до 3-ої лактації із подальшою стабілізацію на практично однаковому рівні, тобто, патерн $1<2<3=4+$. Він був відмічений як серед досліджених нами корів, а також, наприклад, корів голштинської породи в Угорщині (Jonas et al., 2016), Kopeї (Vijayakumar et al., 2017) та ін. В другому випадку рівень молочної продуктивності досягає свого максимального значення вже під час другої лактації, тобто, характеризується патерном $1<2=3+$, який було відмічено серед корів голштинської або голштино-фризької породи в Марокко (Talbi and El Madidi, 2015), Сгипті (Rushdi, 2015), Китаю (Yang et al., 2013) та ін.

Встановлено й значний вплив на рівень молочної продуктивності (як за окремі місяці, так і за 305 днів лактації загалом) серед корів різних генерацій. Знову ж, в найбільшому ступені він виражений протягом 23-го місяців лактації, тоді як наприкінці лактації (7-8й місяці) вплив року народження корів не проявлявся (див. табл. 1).

Загалом, тварини 2001-2003 років народження (група G1) вирізнялися найнижчими оцінками молочної продуктивності протягом всіх десяти місяців лактації (рис. 3). Для корів генерацій G2 та G3 притаманні лактаційні криві майже однакової форми, для якої характерно суттєве збільшення надоїв протягом перших трьох місяців лактації. А тварини генерації G4 хоча і поступалися двом попереднім групам у відношенні надоїв за 1-4-й місяці лактації, проте характеризувалися повільнішим зниженням лактаційної діяльності (див. рис. 3).

Сезон отелення не впливав на надій корів за 305 днів лактації (див. табл. 1).

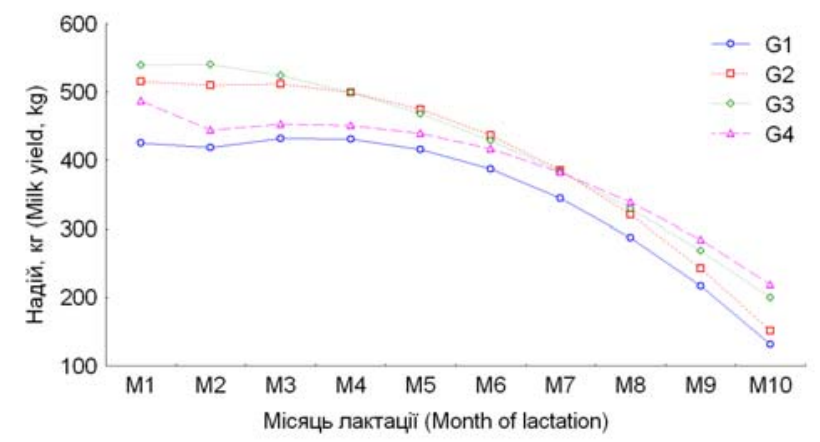

Рис. 3. Лактаційні кривих корів залежно від генерації

Хоча на окремі етапи лактації вплив сезону отелення був суттєвий (за винятком 3-го та 9-го місяців лактації). Прояв сезону отелення простежується насамперед у відношенні форми лактаційної кривої тварин із зимовими отеленнями - відмічається поступове зростання надоїв від 1-го місяця лактації до 4-го, а потім їх дуже різке зниження (рис. 4).

Водночас як для решти корів лактаційні криві характеризуються повільнішим спадом лактаційної діяльності протягом 3-10-го місяців лактації (див. рис. 4).

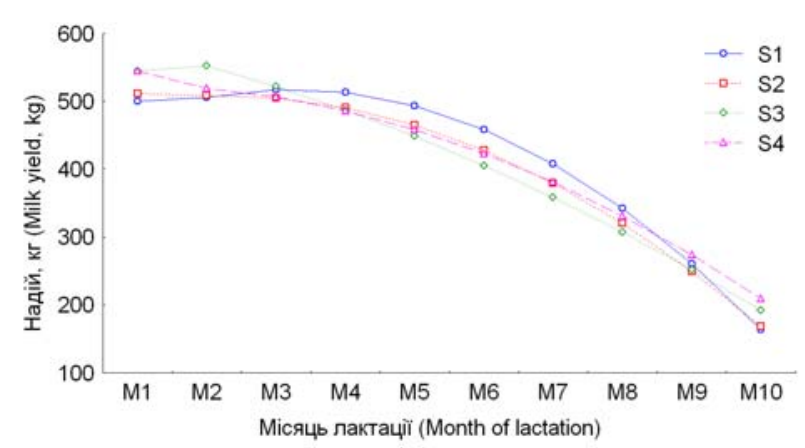

Рис. 4. Лактаційні кривих корів залежно від сезону отелення

B роботі (Wood, 1970) наведено результати аналізу впливу сезону (або календарного місяця) отелення на рівень молочної продуктивності корів та показано, що тварини, які отелилися в жовтні-грудні характеризуються максимальними надоями та суттєво переважають корів, що отелилися в травні-червні.

Більш пізні роботи також підтверджують наявність цієї закономірності і в країнах з помірним кліматом (Horn et al., 2014; Jonas et al., 2016), і в таких жарких, як Туніс (Bedhiaf-Romdhani and Djemali, 2017) або Іран (Torshizi, 2016). При цьому встановлено, що сезон отелення регулює отриманий за лактацію надій за рахунок зміни форми лактаційної кривої й насамперед підвищення іiі персистентності (Корес et al., 2013; Torshizi, 2016). Як і в нашому випадку, для первісток голштинської породи в умовах Кореї сезон отелення впливав насамперед на надої за окремі стадії лактації, особливо протягом 4-8-го місяців (Won et al., 2014).

Сумісний вплив бугая-плідника та номера лактації мав різний прояв на ознаки молочної продуктивності тварин (рис. 5).

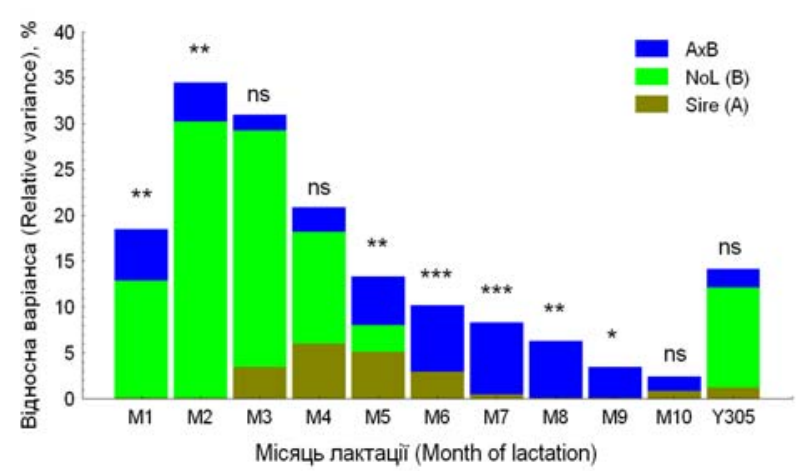

Рис. 5. Оцінки частки мінливості (у \%) впливу бугая-плідника (Sire), номера лактації (NoL) та їх взаємодії на ознаки молочної продуктивності корів

(Відмічено вірогідність GEI-ефекту: * $-\mathrm{P}<0,05$; ** $-\mathrm{P}<0,01 ; * * *-\mathrm{P}<0,001 ; \mathrm{ns}-\mathrm{P}>0,05)$

Але при цьому нами відзначено й вірогідний сумісний вплив цих факторів, який більше проявляється протягом перших двох місяців та другої половини лактації. Хоча в цілому для надою за 305 днів лактації вірогідного впливу GEI-ефекту не відмічено (див. рис. 5).

Сумісний вплив року народження корів (генерація) та генотипового фактора (бугай-плідник) також в 
більшому ступені проявлявся для показників надою за 2-3-й та 6-10-й місяці лактації, але для сумарного надою за 305 днів лактації, знову ж, вірогідного прояву їх сполучення не встановлено (рис. 6).

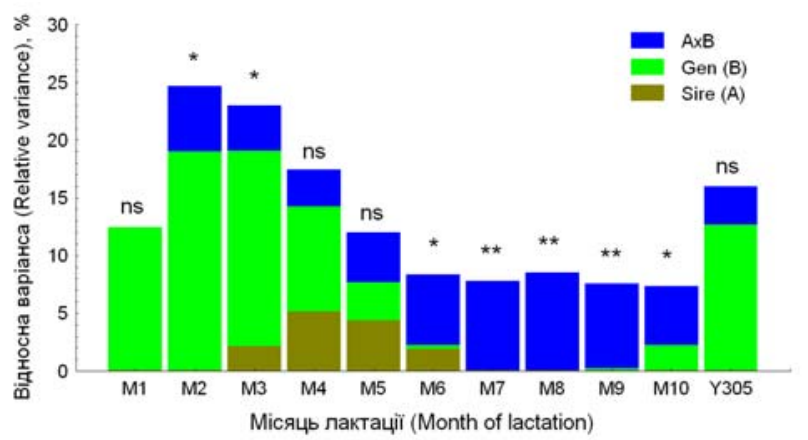

Рис. 6. Оцінки частки мінливості (у \%) впливу бугаяплідника (Sire), генерації (Gen) та їх взаємодії на ознаки молочної продуктивності корів

(Відмічено вірогідність GEI-ефекту: * $-\mathrm{P}<0,05$; $* *-\mathrm{P}<0,01 ; * * *-\mathrm{P}<0,001 ; \mathrm{ns}-\mathrm{P}>0,05$.)

Вірогідний вплив сполучення “бугай-плідник $\times$ ceзон отелення корови” був відсутній як для окремих місяців лактації, так і для сумарного надою за 305 днів лактації. Винятком $є$ лише показники надою протягом останньої третини лактації (тобто, М8-М10) (рис. 7).

В роботі (Ron and Hillel, 1983) також було встановлено вірогідний GEI-ефект сполучення “бугайплідник $\times$ номер лактації корови”, а також “бугайплідник $\times$ рік лактаціі”. На підставі отриманих результатів авторами було зроблено висновок, що оцінку племінної цінності бугаїв-плідників необхідно проводити з урахуванням даних їх дочок за декілька лактацій, а не лише першої.

Вірогідний ефект взаємодії бугаїв-плідників із роком (чи сезоном) отелення їх дочок найчастіше проявлявся при розгляді рівня мінливості нащадків певних бугаїв, що утримуються в різних господарствах (стадах). Так, для голштино-фризьких корів господарств Великої Британії було відмічено вірогідна взаємодія сполучення “бугай-плідник $\times$ стадо-ріксезон отелення" (Meyer, 1987), а для голтинськіх корів господарств США - вірогідна взаємодія сполучень “бугай-плідник $\times$ стадо”, “бугай-плідник $\times$ стадо $\times$ рік” та “бугай-плідник $\times$ стадо $\times$ рік $\times$ сезон отелення" (Dimov et al., 1995).

Варто окремо відзначити, що у більшості випадків для корів дослідного стада вірогідний GEI-ефект проявлявся насамперед для надоїв за другу половину лактації, тобто, він обумовлює не так пік продуктивності, як швидкість зниження молочної продуктивності після досягнення піку, тобто, персистентність (persistency) лактаційної кривої. Даний показник також характеризувався значною мінливістю у тварин залежно від року народження та місяця отелення (Kramarenko et al., 2017).

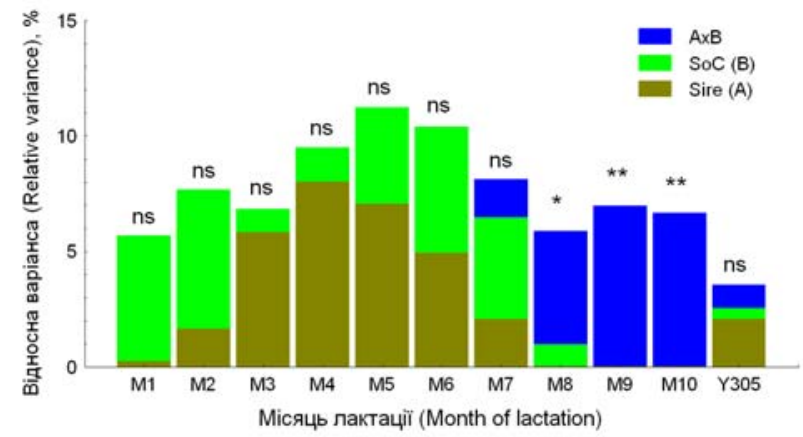

Рис. 7. Оцінки частки мінливості (у \%) впливу бугаяплідника (Sire), сезону отелення (SoC) та їх взаємодії на ознаки молочної продуктивності корів (Відмічено вірогідність GEI-ефекту: * $-P<0,05$; ** $-P<0,01 ; * * *-P<0,001 ; \mathrm{ns}-P>0,05$.

Як відомо, існує дві форми прояву GEI-ефекту ефект масштабу (scaling effect) та ефект зміни рангу (re-ranking effect). В першому випадку оцінка фенотипу тварин двох (чи більше) генотипів змінюється практично пропорційно при їх утриманні в двох (чи більше) градаціях фактора “середовище”. В другому ця зміна для різних генотипів відбувається порізному, що призводить до зміни відносного рангу їх фенотипової оцінки (Нammami et al., 2009). В деяких випадках обидві ці форми можуть зустрічатися разом.

Нами було досліджено, яка 3 цих форм прояву GEI-ефекту зустрічалася для корів дослідного стада. Дизайн двофакторного дисперсійного аналізу (з фіксованими факторами) був неповний для 4-ої лактації та генерації G1, тому їх було виключено з подальшого аналізу.

Для сполучення "бугай-плідник $\times$ номер лактації" відмічався вірогідний вплив генотипового фактора, віку корів (у лактаціях) та їх сумісної дії на сумарний надій корів за 305 днів лактації (рис. 8).

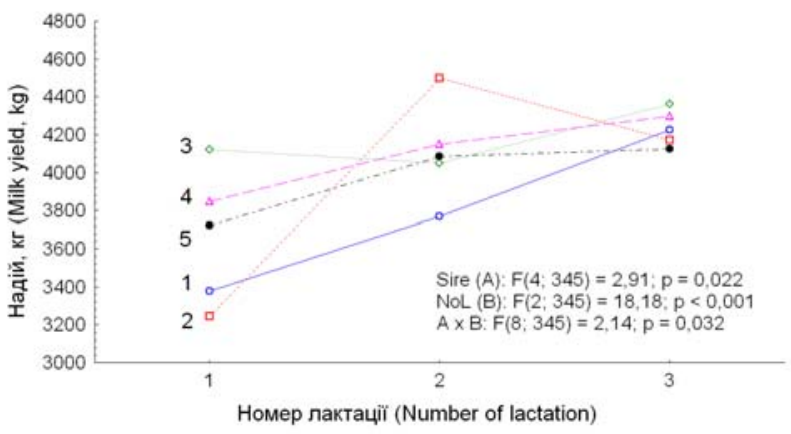

Рис. 8. Аналіз сумісного впливу

бугая-плідника (Sire) та номеру лактації (NoL) на надій за 305 днів лактації

(1 - Орфей, 2 -Тангенс, 3 - Нарцис, 4 - Тополь, 5 - Памір)

Таким чином, під час 1-ої та 2-ої лактації відбувалася значна зміна рангу бугаїв-плідників стосовно надою їх дочок. Так, нащадки бугая Тангенса характеризувалися в середньому найнижчим надоєм за 1-у лактацію, але вони значно переважали своїх ровесниць під час 2-ої лактації. Лише нащадки Тополя зберігали свій ранг протягом 1-3-ої лактації (див. рис. 8). Під час 3-ої лактації тварини характеризува- 
лися відносно близькими оцінками надою незалежно від їхнього походження.

У розрізі генерацій отримані вище закономірності практично повністю зберігалися - відмічається вірогідний вплив й бугая-плідника, і генерації (хоча й майже на межі вірогідності), а також їх сумісний вплив (рис. 9).

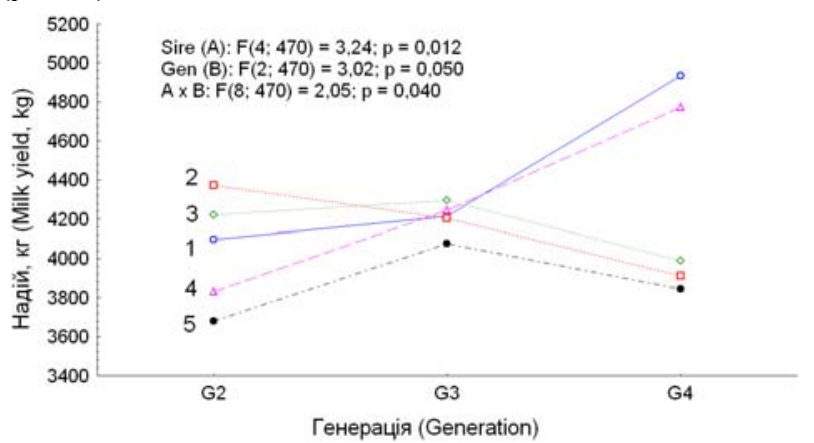

Рис. 9. Аналіз сумісного впливу бугая-плідника (Sire) та генерації (Gen) на надій за 305 днів лактації (1 - Орфей, 2 -Тангенс, 3 - Нарцис, 4 - Тополь, 5 - Памір)

Ранг бугаїв-плідників значно змінювався, особливо, при порівнянні генерацій G2 та G4. Так, для генерації G2 нащадки бугая-плідника Орфей та Тополь займали третій та четвертий ранг, відповідно, тоді як для генерації G4 - перший та другий, відповідно. 3 іншого боку, нащадки Паміру характеризувалися найнижчим рівнем молочної продуктивності, незалежно від року народження (див. рис. 9).

Що стосується впливу сезону отелення, то, як вже було вказано вище, сумісного впливу “бугай-плідник × сезон отелення корови” на надій за 305 днів лактації нами встановлено не було (див. рис. 7).

Таким чином, стосовно сумарного надою за 305 днів лактації тварин дослідного стада нами було встановлено вірогідний прояв GEI-ефекту для сполучень “бугай-плідник $\times$ номер лактації корови” та "бугайплідник $\times$ генерація корови”. В обох випадках він був виражений у формі ефекту зміни рангу. Прояв GEIефекту у вигляді зміни рангу бугаїв-плідників було раніше відмічено серед худоби молочного напрямку (Kolmodin et al., 2002; Raffrenato et al., 2003).

Вірогідний вплив сполучення “бугай-плідник $\times$ сезон отелення корови” було відмічено лише для показників надою протягом третьої третини лактації (M8M10).

\section{Висновки}

1. Рівень молочної продуктивності корів дослідного стада (як за окремі місяці лактації, так і за 305 днів) вірогідно залежав від генотипового фактора (бугайплідник). Особливо це проявлялося під час 3-6-го місяців лактації, тобто, протягом періоду максимальної реалізації молочної продуктивності тваринами.

2. Вік корів (виражений у порядковому номері лактаціі) суттєво впливав як на сумарний надій за 305 днів лактації, так і на надої протягом перших шести місяців лактації.

3. Встановлено й значний вплив на рівень молочної продуктивності (як за окремі місяці, так і за 305 днів лактації загалом) серед корів різних генерацій. В найбільшому ступені він виражений протягом 2-3-го місяців лактації.

4. Сезон отелення не впливав на надій корів за 305 днів лактації, тоді як на окремі етапи лактації вплив сезону отелення був суттєвий (за винятком 3-го та 9го місяців лактації). Прояв сезону отелення проглядається насамперед стосовно зміни форми лактаційної кривої тварин із зимовими отеленнями.

5. Вірогідний GEI-ефект проявлявся насамперед для надоїв за другу половину лактації, тобто він обумовлює не так пік продуктивності, як швидкість зниження молочної продуктивності після досягнення піку, тобто персистентність (persistency) лактаційної кривої.

6. Стосовно сумарного надою за 305 днів лактації тварин дослідного стада нами було встановлено вірогідний прояв GEI-ефекту для сполучень “бугайплідник $\times$ номер лактації корови” та “бугай-плідник $\times$ генерація корови”. В обох випадках він був виражений у формі ефекту зміни рангу.

Подяки. Робота виконана в рамках держбюджетної тематики Міністерства освіти і науки України (номер державної реєстрації 0117U000485).

\section{References}

Adamczyk, K., Makulska, J., Jagusiak, W., \& Węglarz, A. (2017). Associations between strain, herd size, age at first calving, culling reason and lifetime performance characteristics in Holstein-Friesian cows. Animal, 11(2), 327-334. doi: 10.1017/S1751731116001348.

Bedhiaf-Romdhani, S., \& Djemali, M. (2017). Study of the environmental effects on Holstein cows' milk performance under Tunisian conditions. Universal Journal of Agricultural Research, 5(4), 209-212. doi: 10.13189/ujar.2017.050401.

Broucek, J., Kisac, P., Hanus, A., Uhrincat, M., \& Foltys, V. (2004). Effects of rearing, sire and calving season on growth and milk efficiency in dairy cows. Czech Journal of Animal Science, 49(8), 329-339. doi: 10.17221/4317-CJAS.

Dimov, G., Albuquerque, L.G., Keown, J.F., Van Vleck, L.D., \& Norman, H.D. (1995). Variance of interaction effects of sire and herd for yield traits of Holsteins in California, New York, and Pennsylvania with an Animal Model. Journal of Dairy Science, 78(4), 939946. doi: 10.3168/jds.S0022-0302(95)76709-1.

ElBoshra, M.E., Ali, T.E., \& Hassabo, A.A. (2016). Genetic and environmental factors affecting 305-day mature equivalent milk yield of Holstein Friesian cows in the United Arab Emirates. Journal of Agricultural and Marine Sciences, 21(1), 2-7. doi: 10.24200/ jams.vol21 iss0pp1-6.

Falconer, D.S., \& Mackay, T.F.C. (1996). Introduction to Quantitative Genetics. Harlow: Longman Group Ltd.

Haile-Mariam, M., Carrick, M.J., \& Goddard, M.E. (2008). Genotype by environment interaction for fertility, survival, and milk production traits in Australian dairy cattle. Journal of Dairy Science, 91(12), 48404853. doi: $10.3168 /$ jds.2008-1084. 
Halafyan, A.A. (2007). STATISTICA 6. Statisticheskij analiz dannyh. Moscow: "Binom-Press" Ltd. (in Russian).

Hammami, H., Rekik, B., \& Gengler, N. (2009). Genotype by environment interaction in dairy cattle. Biotechnologie, Agronomie, Societe et Environnement, 13(1), 155-164.

Hammoud, M.H., El-Zarkouny, S. Z., \& Oudah, E.Z.M. (2010). Effect of sire, age at first calving, season and year of calving and parity on reproductive performance of Friesian cows under semiarid conditions in Egypt. Archiva Zootechnica, 13(1), 60-82.

Hayes, B.J., Carrick, M., Bowman, P., \& Goddard, M.E. (2003). Genotype x environment interaction for milk production of daughters of Australian dairy sires from test-day records. Journal of Dairy Science, 86(11), 3736-3744. doi: 10.3168/jds.s0022-0302(03)73980-0.

Hayes, B.J., Daetwyler, H.D., \& Goddard, M.E. (2016). Models for genome $\mathrm{x}$ environment interaction: examples in livestock. Crop Science, 56(5), 2251-2259. doi: 10.2135/cropsci2015.07.0451.

Horan, B., Dillon, P., Berry, D. P., O'Connor, P., \& Rath, M. (2005). The effect of strain of Holstein-Friesian, feeding system and parity on lactation curves characteristics of spring-calving dairy cows. Livestock Production Science, 95(3), 231-241. doi: 10.1016/j.livprodsci.2004.12.021.

Horn, M., Steinwidder, A., Starz, W., Pfister, R., \& Zollitsch, W. (2014). Interactions between calving season and cattle breed in a seasonal Alpine organic and low-input dairy system. Livestock Science, 160, 141-150. doi: 10.1016/j.livsci.2013.11.014.

Jonas, E.M., Atasever, S., Graff, M., \& Erdem, H. (2016). Non-genetic factors affecting milk yield, composition and somatic cell count in Hungarian Holstein cows. Kafkas Üniversitesi Veteriner Fakültesi Dergisi, 22(3), 361-366. doi: 10.9775/kvfd.2015.14672.

Kolmodin, R., Strandberg, E., Madsen. P., Jensen, J., \& Jorjani, H. (2002) Genotype by environment interaction in Nordic dairy cattle studied using reaction norms. Acta Agriculturae Scandinavica, Section A - Animal Science, 52(1), 11-24, doi: 10.1080/09064700252806380.

Kopec, T., Chládek, G., Kučera, J., Falta, D., Hanuš, O., \& Roubal, P. (2013). The effect of the calving season on the Wood's model parameters and characteristics of the lactation curve in Czech Fleckvieh cows. Archives Animal Breeding, 56(1), 808-815. doi: 10.7482/0003-9438-56-080.

Kramarenko, S.S. (2008). Novi metody matematychnoho modelyuvannya laktatsiynykh kryvykh za dopomohoyu interpolyatsiyi. In: Materialy mizhnarodnoyi naukovo-praktychnoyi konferentsiyi "Novitni tekhnolohiyi skotarstva u XXI stolitti”. Mykolayiv: MDAU (in Ukrainian).

Kramarenko, S.S., Kuz'michova, N.I., \& Kramarenko, O.S. (2017). Modelyuvannya laktatsiynykh kryvykh molochnykh koriv za dopomohoyu analizu holovnykh komponent (PCA). Visnyk ahrarnoyi nauky Prychornomor'ya, 96(4), 115-125 (in Ukrainian).
Kuznecov, V.M. (2001). Sovremennye metody analiza i planirovaniya selektsii $\mathrm{v}$ molochnom stade. Kirov: Zonal'nyy NIISKh Severo-vostoka (In Russian).

Meyer, K. (1987). Estimates of variances due to sire $\mathrm{x}$ herd interactions and environmental covariances between paternal half-sibs for first lactation dairy production. Livestock Production Science, 17, 95-115. doi: 10.1016/0301-6226(87)90057-1.

Montaldo, H.H. (2001). Genotype by environment interactions in livestock breeding programs: a review. Interciencia, 26(6), 229-235.

Montaldo, H.H., Castillo-Juarez, H., Lizana, C., Trejo, C., Cienfuegos-Rivas, E.G., \& Pelcastre-Cruz, A. (2015). Genotype-environment interaction between Chile and North America and between Chilean herd environmental categories for milk yield traits in black and white cattle. Animal Science Papers and Reports, 1(33), 23-33.

Nauta, W.J., Veerkamp, R.F., Brascamp, E.W., \& Bovenhuis, H. (2006). Genotype by environment interaction for milk production traits between organic and conventional dairy cattle production in the Netherlands. Journal of Dairy Science, 89(7), 2729-2737. doi: 10.3168/jds.s0022-0302(06)72349-9.

Raffrenato, E., Blake, R.W., Oltenacu, P.A., Carvalheira, J., \& Licitra, G. (2003). Genotype by environment interaction for yield and somatic cell score with alternative environmental definitions. Journal of Dairy Science, 86(7), 2470-2479. doi: 10.3168/jds.S00220302(03)73841-7.

Ron, M., \& Hillel, J. (1983). Genotype x environment interaction in dairy cattle and its role in breeding programmes. Theoretical and Applied Genetics, 66(2), 93-99. doi: 10.1007/BF00265180.

Rushdi, H.E. (2015). Genetic and phenotypic analyses of days open and 305-day milk yield in a commercial Holstein Friesian herd. Egyptian Journal of Animal Production, 52(2), 107-112.

Sundberg, T., Rydhmer, L., Fikse, W. F., Berglund, B., \& Strandberg, E. (2010). Genotype by environment interaction of Swedish dairy cows in organic and conventional production systems. Acta Agriculturae Scandinavica, Section A - Animal Science, 60(2), 6573. doi: 10.1080/09064702.2010.496003.

Talbi, A., \& El Madidi, S. (2015). Effets des facteurs environnementaux sur la production laitiure des vaches Holstein dans la region de Souss-Massa au Maroc. Livestock Research for Rural Development, 27, 116. http://www.lrrd.org/lrrd27/6/talb27116.html.

Torshizi, M.E. (2016). Effects of season and age at first calving on genetic and phenotypic characteristics of lactation curve parameters in Holstein cows. Journal of Animal Science and Technology, 58(1), 8. doi: 10.1186/s40781-016-0089-1.

van der Laak, M., van Pelt, M.L., De Jong, G., \& Mulder, H.A. (2016). Genotype by environment interaction for production, somatic cell score, workability, and conformation traits in Dutch Holstein-Friesian cows between farms with or without grazing. Journal of Dairy Science, 99(6), 4496-4503. doi: 10.3168/jds.201510555. 
Vijayakumar, M., Park, J.H., Ki, K.S., Lim, D.H., Kim, S.B., Park, S.M., Jeong, H.Y., Park, B.Y., \& Kim, T.I. (2017). The effect of lactation number, stage, length, and milking frequency on milk yield in Korean Holstein dairy cows using automatic milking system. Asian-Australasian journal of animal sciences, 30(8), 1093-1098. doi: 10.5713/ajas.16.0882.

Zwald, N.R., Weigel, K.A., Fikse, W.F., \& Rekaya, R. (2003). Identification of factors that cause genotype by environment interaction between herds of Holstein cattle in seventeen countries. Journal of Dairy Science, 86(3), 1009-1018. doi: 10.3168/jds.S00220302(03)73684-4.
Wood, P.D.P. (1970). The relationship between the month of calving and milk production. Animal Production, 12(2), 253-259. doi: 10.1017/S0003356100038824.

Won, J.I., Jung, Y.S., Lim, H.J., Kim, S.D., Cho, M.R., Min, H.L., Im. S.K., Kwon, E.G. \& Yoon, H.B. (2014). Influences of calving season on the lactation curve of first parity Holstein in Korea. Journal of Agriculture \& Life Science, 48(6), 233-242. (In Korean). doi: 10.14397/jals.2014.48.6.233.

Yang, L., Yang, Q., Yi, M., Pang, Z.H., \& Xiong, B.H. (2013). Effects of seasonal change and parity on raw milk composition and related indices in Chinese Holstein cows in northern China. Journal of Dairy Science, 96(11), 6863-6869. doi: 10.3168/jds.2013-6846. 